\title{
Response of Peanut to Some Kinds of Organic Fertilizers under Drip and Sprinkler Irrigation Systems
}

\author{
Abd El-Halim 1 , A. K., A.M Awad ${ }^{2}$ and M. E Moursy²
}

\begin{abstract}
Two field experiments were conducted at EL- Bustan area (Nubaria region) sandy calcareous soil in Two Successive summer seasons, 2007 -2008 and 2008-2009. The main objectives of this study were to test the effect of two irrigation system, $\left(I 1=\right.$ sprinkler irrigation and $I_{2}=$ drip irrigation system with $100 \%$ of ETp), and 5 treatments of organic fertilizers with two system (sprinkler and drip) on peanut yield, oil percentage, water requirements, water consumption, water productivity.

Results revealed that there were significant deference effects due to the interaction between the soluble organic fertilizers and two irrigation systems on the peanut production through the two growing seasons. The highest yield of peanut were 18.99 and $25.52 \mathrm{ardab} / \mathrm{fed}$, in the first and second seasons, respectively with sprinkler system compared with drip irrigation system. Also, the highest peanut yields were 20.47 and 27.53 ardab/fed with soaked poultry glaucoma in two seasons respectively. Also, the effect of irrigation system on the oil\% was in second season with sprinkler system, it was 48.2 and $46.2 \%$ with sprinkler and drip irrigation system respectively. And the highest oil\% with soaked pigeons manure it were 53.1 and $52.3 \%$ in two growing season respectively.

The water requirements for the irrigation of $100 \%$ of ETp was 65.5 and $73.0 \mathrm{~cm}$ with sprinkler irrigation system and 58.0 and $68.9 \mathrm{~cm}$ with the drip irrigation system in two growing seasons respectively. The highest values of water productivity were $1.32 \mathrm{~kg}$ peanut seeds $/ \mathrm{m} 3$ applied irrigation water with sprinkler irrigation in the second season.
\end{abstract}

Key words:- Drip irrigation- Peaunt- Fertigation- Likued organic fertilizers- irrigation productivity water.

\section{INTRODUCTION}

Irrigation is critical for successful summer plant production in Mediterranean countries. Irrigation should be efficient and effective in order to avoid over or under application. Over application is a wasteful use of a nature resource which may lead to erosion and surface water or ground water contamination and which costs a lot of money. Under application can result in yield depression or crop loss. Efficient irrigation systems require the selection of an appropriate method for the crop growth, adequate monitoring of the irrigation system and of water delivery and appropriate application rates depending on the growth stage of the crop. Irrigation requirements differ depending on the locations, soil types and cultural practices (Bilalis et. Al., 2009). In recent years, the cost of the installation has relatively decreased, because of the technology improving. Advanced of drip irrigation systems compared to the sprinkler and furrow irrigation systems, includes reduced water use (Cetin and Bilgel, 2002; Sharmasarkar et al., 2001) and decreased weed growth (Karkanis et al., 2007). Also, other investigators have also reported high yields for crops under drip irrigation (Cetin and Bilgel, 2002). Economic use of water is a vital problem which confronts farmers and agricultural scientists in irrigated areas of arid and semi-arid regions Knowledge of the right amounts of irrigation water is essential to obtain economically maximum yield of different crops. Improper irrigation water operation accounts for significant water losses in some large irrigation schemes .Consequently, the use of modern irrigation systems in irrigation operation and scheduling is essential for the reduction of irrigation water demands (Brown, 1999). The water use efficiency (WUE) of surface drip irrigation is higher than that of sprinkler irrigation system. Attia et al.(2005) revealed that the higher water utilization efficiency values were 393 and $3.69 \mathrm{~kg}$ tuber sweet potato per $\mathrm{m}^{3}$ irrigation eater in the first and second season in sandy soil, respectively. Crop water productivity (WP) or water use efficiency (WUE) expressed in $\mathrm{kg} / \mathrm{m}^{3}$ is an efficiency term, expressing the amount of marketable product (e.g. kilograms of grain) in relation to the amount of input needed to produce that output (cubic meters of water). The water used for crop production is referred to as crop evapotranspiration. This is a combination of water lost by evaporation from the soil surface and transpiration by the plant, occurring simultaneously. Except by modeling, distinguishing between the two processes is difficult. Representative values of WUE for cereals at field level, expressed with evapotranspiration in the denominator, can vary between 0.10 and $4 \mathrm{~kg} / \mathrm{m}^{3}$ (Zwart and Bastiaanssen, 2004). The agricultural production and the development of arid and semi-arid regions rely mainly on irrigation. However, without appropriate management, irrigated agriculture can be detrimental to the environment and endanger sustainability. Therefore, the goal of modern irrigation is to develop methods allowing to save water and to improve both the water and the salt distribution within

${ }^{1}$ Water Requirements and Field Irrigation Department.

${ }^{2}$ Plant Fertility Department.

Received November 24, 2016, Accepted December 26, 2016 
the root zone, also preserving maintenance of good structural conditions (Crescimanno et. al., 2007).

Peanut (Arachis hypogaea L.) is considered one of the most important edible oil crops in Egypt, which is due to its seeds' high nutritive value for humans, as well as the produced cake and the green leafy hay for feeding livestock, in addition to the seed oil's importance for industrial purposes. The main growing areas are located in the north of the country; they include reclaimed desert to the east and west of the Nile Delta. Peanut seeds are characterized by their high oil content $(50 \%)$, which is utilized in different industries, besides they contain 26-28\% protein, 20\% carbohydrates and 5\% fiber (Fageria et al., 1997). Peanut is an important legume cash crop for the farmers in arid and semi-arid regions and its seeds contain high amounts of edible oil (43-55\%), protein (25-28\%), and minerals $(2.5 \%)$. As a result of the continuous population explosion and the increasing standard of living, the demand on agricultural productivity and water resources is sharply increasing. Improper irrigation management not only causes variation in crop yield but also wastes scarce and valuable water resources. Deficit irrigation as an agricultural water management system is an effective way for managing water shortages. Better management of deficit irrigation requires a proper understanding of the effect of irrigation water on crop growth and yield under different growing conditions. Abundant soil moisture is required for normal development of peanut at all stages of growth. However, under limited availability of water, scheduling of irrigation at the critical stages or eliminating the least productive irrigations could increase crop productivity and water use efficiencies of peanut (Abdrabbo, 2009). Sprinkler irrigation systems with low irrigation frequencies of $3 \mathrm{~d}$ increased pod yield of peanut (ranged from 602 to $651 \mathrm{~g} \mathrm{~m}$ 2) and WUEs due to decreasing water losses during the irrigation season (Plaut and Ben-Hur, 2005). They also stated that total water applied to peanut crop ranged from 575 to $648 \mathrm{~mm}$. reported that by Ahmad (1999) the total water requirements of peanut may range from 500 to $700 \mathrm{~mm}$ throughout the growing season. Better management of water resources can be achieved by developing site- and cultivar-specific Kc and estimation of phonological parameters. Comprehensive knowledge (Macro-management) of actual evapotranspiration, crop coefficient $(\mathrm{Kc})$, crop water requirements, and critical crop growth stages are very important for optimizing crop water use and maximizing crop yield (Elliott et al., 1988; Jain et al., 1997; Bandyopadhyay et al., 2005; Suleiman et al., 2007). Also, peanut (Arachis hypogaea $L$.) is a crop that can enter the human diet in various forms or be used as an alternative resource for livestock or industrial applications (Faircloth et al., 2008). The high protein above ground biomass can be used as an animal feed and the oil has multiple industrial applications, including bio-fuel, specifically biodiesel. As demand for organic products increases it is likely that the demand for organically produced peanut products will also increase. As a nitrogen fixing crop, peanut would be an outstanding rotational crop for many organic production systems, while providing a diversity of uses beyond human consumption.

Application of organic fertilizers is one of important practical measures to improve soil fertility. In addition to providing necessary nutrients for crops and improving soil physico-chemical properties, organic fertilizer is able to enhance soil microbial activity of soil, such as improving activity of soil enzymes and increasing soil microbial biomass (Ren et al. 1996; Sun et al. 2003; Lv et al. 2005). All fertilizer treatments increased both peanut legume yield and biomass compared no fertilization (CK), with the higher increment in the treatments of monosodium glutamate. Plate count and Denaturing Gradient Gel Electrophoresis (DGGE) analysis have demonstrated that application of organic manure substantially increased soil microbial biomass and microbial community (species) diversity (Lin et al, 2010).

The objective of this research is to study the effect of irrigation system and organic fertilizers on peanut yield and oil percentage, water requirements, water consumptive use, water productivity efficiency, under sprinkler and drip irrigation systems.

\section{MATERIALS AND METHODS}

Two field experiments were conducted at Aly Mubarak experimental farm al EL-Bustan area south Tahrir region during 2007- 2008, and 2008 -2009 summer growing seasons. The experimental site represents the newly reclaimed sandy soils where modern irrigation systems (drip and sprinkler) are introduced to the farm. The drip irrigation system used in the experimental farm includes an irrigation pump connected to sand and screen filters and venture injector, control values, water flow meters, and pressure gauges. The distribution system consisted of PVC pipes (Polyvinyl Chloride), which were used as the mainline (75mm diameter) and manifolds (63 $\mathrm{mm}$ diameter) for supplying and discharging water to each plot. Irrigation laterals that were $16 \mathrm{~mm}$ in diameter and 30 meter length had in line emitters (drippers) spaced $0.3 \mathrm{~m}$ apart with $3.6 \mathrm{~L} \mathrm{~h}^{1-}$ flow rate at pressure of $100 \mathrm{kpa}$ (1 bar). The solid set type was used as the sprinkler irrigation system. In this system, PVC pipes and hydrants were used and the main and lateral lines consisted of PVC pipes with 110 and $75 \mathrm{~mm}$ diameters, respectively. 
The distance between sprinklers was $7 * 9 \mathrm{~m}$. Fertilizer tanks were placed at the upper end of the main line and used for nitrogen, phosphorus and potassium applications. The actual discharge of sprinkler was 0.5 $\mathrm{m}^{3} \mathrm{~h}^{-1}$ at an average operating pressure of $150 \mathrm{Kpa}(1.5$ bar).

The class A pan in the experimental farm used to determine the amounts of applied irrigation water to the tested irrigation treatments.

Mechanical analysis and hydro physical parameters for the soil of the experimental site were determined and listed in Table 2.

The tested variables in this experimental comprised two irrigation system (drip and sprinkler) and five organic fertilizers treatments as following:

$\mathrm{I}_{1}=$ Sprinkler irrigation system $(100 \%$ of ETp $)$

$\mathrm{I}_{2}=$ Drip irrigation system $(100 \%$ of ETp $)$, Evapotranspiration (ETp) determined by class A pan.

\section{The organic fertilizers:}

1- Fulvic acid

2- Humic acid

3- Soaked poultry glaucoma

4- Soaked pigeons manure

5- Soaked farmyard manure

Humic and Fulvic acid were extracted from welldecomposed organic manure. The soaked poultry glaucoma, soaked pigeon manure and soaked farmyard manure were soaked for 1 week then injected the extract with irrigation water according to treatments for number
3 times with rate $200 \mathrm{~L}$ soaked/fed and the analysis presented in table (1).

A split plot experimental design with four replicates was used. The main plots were assigned to irrigation systems (drip and sprinkler), while the sub plots were assigned to the organic fertilizers treatments.

During the growing seasons, $90 \mathrm{~kg} / \mathrm{fed} \mathrm{N}$ (as ammonium nitrate, $33.5 \% \mathrm{~N}$ ), $50 \mathrm{Kg} \mathrm{K}_{2} \mathrm{O}$ (as potassium sulfate, $48 \% \mathrm{~K}_{2} \mathrm{O}$ ) and $50 \mathrm{Kg} \mathrm{P}_{2} \mathrm{O}_{5}$ (as phosphoric acid $85 \% \mathrm{P}_{2} \mathrm{O}_{5}$ ) were injected through the irrigation water in 10 and 5 doses for drip and sprinkler irrigation systems, respectively.

Giza 5, peanut variety was sown on the $10^{\text {th }}$ of May and $10^{\text {th }}$ May and was. Harvested on $10^{\text {th }}$ and $11^{\text {th }}$ of September in the first and second seasons, respectively.

The amounts of irrigation water were calculated according to the equation given by Vermeiren and Jopling (1984) as follows:

$$
A I W=\frac{\operatorname{ETp} \times K \operatorname{En} I}{\operatorname{Ea}(1-L R)} \quad \text { Where: }
$$

$\mathrm{AIW}=$ depth of applied irrigation water in, $\mathrm{mm}$

$\mathrm{ETp}=$ potential evapotranspiration $\mathrm{mmd}^{-1}$

$\mathrm{Kc}=$ crop coefficient

$\mathrm{I}=$ irrigation intervals (days) (the irrigation intervals have been estimated based on pan of evaporation in the field and soil physical properties)

$\mathrm{Ea}=$ irrigation application efficiency of the drip and sprinkler irrigation system.

$\mathrm{LR}=$ leaching requirements, (Used the leaching requirements as constant value according the previous experiments in same area)

Table 1. The analysis of organic fertilizers

\begin{tabular}{llccc}
\hline \multirow{2}{*}{$\mathbf{S} / \mathbf{N}$} & \multirow{2}{*}{ Organic fertilizers } & \multicolumn{3}{c}{$\mathbf{g m} / \mathbf{L}$} \\
\cline { 3 - 5 } & & $\mathbf{N}$ & $\mathbf{P}$ & $\mathbf{K}$ \\
\hline 1 & Fulvic acid & 1.8 & 0.17 & 4.2 \\
2 & Humic acid & 2.2 & 0.16 & 10.0 \\
3 & Soaked poultry glaucoma & 1.8 & 0.32 & 12.1 \\
4 & Soaked pigeons manure & 2.1 & 0.22 & 7.5 \\
5 & Soaked farmyard manure & 1.7 & 0.29 & 14.5 \\
\hline
\end{tabular}

Table 2. Mechanical analysis and hydro physical parameters of the soil site

\begin{tabular}{|c|c|c|c|c|c|c|c|}
\hline \multirow{2}{*}{$\begin{array}{l}\text { Soil depth } \\
\text { Cm }\end{array}$} & \multicolumn{4}{|c|}{ Mechanical analysis } & \multicolumn{3}{|c|}{ Hydro Physical parameters } \\
\hline & Sand $\%$ & Silt \% & Clay \% & Text class & FC\% ${ }^{\#}$ & W.P\%"\# & Bulk density $\mathrm{gcm}^{-3}$ \\
\hline $0-15$ & 91.5 & 3.5 & 5.0 & Sandy & 8.80 & 4.70 & 1.44 \\
\hline $15-30$ & 91.9 & 3.2 & 4.9 & Sandy & 8.70 & 4.60 & 1.63 \\
\hline $30-45$ & 92.0 & 3.0 & 5.0 & Sandy & 8.50 & 4.50 & 1.70 \\
\hline $45-60$ & 92.5 & 2.8 & 4.7 & Sandy & 8.30 & 4.40 & 1.75 \\
\hline Average & & & & & 8.6 & 4.60 & 1.63 \\
\hline
\end{tabular}

\footnotetext{
\# Field capacity ${ }^{\# \#}$ wilting point
} 
Potential evapotranspiration (ETp) values were calculated from class A pan measurements as follows:

$\mathrm{ETp}=\mathrm{Epan} \times \mathrm{K}$ pan (Doorenbos and Pruitt, 1984)

E pan is the measured of pan evaporation values in $\mathrm{mmd}^{-1}$ and Kpan is the pan coefficient that equals 0.75 for the experimental site.

Irrigation time for drip irrigation system was determined before cultivation by measuring the actual emitter discharges according the equation given by Ismail (2002) as follows:

$T=\frac{A I W \times A}{q}$,

Where:

$\mathrm{T}=$ irrigation time $(\mathrm{h})$

$\mathrm{A}=$ wetted area $\left(\mathrm{cm}^{2}\right)$

$\mathrm{q}=$ emitter discharge $(\mathrm{L} / \mathrm{h})$

AIW $=$ applied irrigation water $(\mathrm{mm})$

While, the irrigation time for sprinkler irrigation water was calculated according to the equation as follows:

Irrigation time $(h)=\frac{A F W}{A R}$,

Where:

$\mathrm{AR}=$ application rate $(\mathrm{mm} / \mathrm{h})$

$A R=\frac{1000 \times Q}{L l \times L S}$

$\mathrm{Q}=$ sprinkler discharge $\left(\mathrm{m}^{3} / \mathrm{h}\right)$

$\mathrm{L}_{\mathrm{L}}=$ distance between lateral $(\mathrm{m})$

$\mathrm{Ls}=$ distance between sprinkler $(\mathrm{m})$

Water utilization efficiency (WUtE) values were calculated according to Jensen (1983) as follows:

$$
W U_{*} E=\frac{\text { Peanut yield }\left(\frac{\mathrm{hg}}{\mathrm{fed}}\right)}{\text { applied irrigation water }\left(\frac{\mathrm{m}^{3}}{\mathrm{fez}}\right)}
$$

The water consumptive use (WCU) values were calculated according to Israelson and Hansen (1962) by using the following equation

$$
W C U=\sum_{i=1}^{i-4} \frac{\theta 2-\theta 1}{100} \times d \times \omega
$$

Where:

$\mathrm{WCU}=$ water consumptive use $(\mathrm{cm})$

$\mathrm{i}=$ number of soil layer

$\Theta 2=$ soil moisture content after irrigation \%

$\Theta 1=$ soil moisture content before irrigation $\%$

$\mathrm{d}=$ depth of soil layer $(\mathrm{cm})$ $\varphi=$ soil bulk density $\mathrm{gcm}^{-3}$

Crop coefficient $(\mathrm{Kc})$ values wer calculated as :

$$
K c=\frac{E T a}{E T p} \quad \text { Where: }
$$

$\mathrm{ETa}=$ actual evapotranspiration's or water consumptive use $\left(\mathrm{mmt}^{-1}\right)$

The obtained data were statistically analyzed according to technique of analysis of variance (ANOVA) for the split plot design as described by Steel and Torrie, (1960).

\section{RESULTS AND DISCUSSION}

\section{Peanut yield and oil percentage:}

Effect of irrigation system and bio-fertilizers on the peanut yield and oil percentage in sandy soil during the 2007-2008 and 2008-2009 growing seasons are presented in table (3). Result showed significant effects of all treatments on peanut yield and oil percentage. The sprinkler irrigation system recorded the significant increase peanut yield by 8.69 and $10.83 \%$ in the first and second seasons, respectively as compared with drip irrigation system. The addition of soaked poultry glaucoma as bio fertilizer gave the highest yield of peanut 20.47 and 27.53 ardab/fed for first and second seasons respectively. This was due to improving soil physico-chemical properties and enhancing soil microbial activity of soil, such as improving activity of soil enzymes and increasing soil microbial biomass. These results agree with those reported by Zwart and Bastiaanssen, (2004), Plaut and Ben-Hur, 2005 and Lina et al, (2010).

The effect of irrigation system and bio-fertilizers on peanut oil percentage is presented in Table (3). The results showed that there were no significant different between two irrigation systems in the first season, but in the second season the oil percentage was $48.2 \%$ with sprinkler systems and it was higher than the drip of irrigation system (46.2\%). Regarding bio-fertilizers, the higher values was 53.1 and $52.3 \%$ with organic soaked pigeons manure in first and second seasons, respectively. The interaction effect of sprinkler irrigation system and organic soaked pigeons manure had the highest value of soil percentage in first and second seasons $(54 \%)$. These results were in accordance with Hassan et al., (2005) and Sun et. al., (2003). They reported that oleic acid levels increased regularly with increasing nitrogen and irrigation levels. Also, they reported that soil type, temperature variations, moisture availability and sunshine hours particularly from flowering to maturity were the major determinants of oil and fatty acid accumulation. 
Table 3. The effect of irrigation system and type of organic manure on the yield of peanut in two successive seasons (2007 and 2008)

\begin{tabular}{|c|c|c|c|c|}
\hline \multirow[t]{2}{*}{ Treatment } & \multicolumn{2}{|c|}{$\begin{array}{c}\text { The average Peanut yield } \\
\text { (Ardab/fad) }\end{array}$} & \multicolumn{2}{|c|}{ Oil \% } \\
\hline & Season 2007 & Season 2008 & Season 2007 & Season 2008 \\
\hline \multicolumn{5}{|l|}{ Irrigation system } \\
\hline Sprinkler & 18.99 & 25.52 & 49.1 & 48.2 \\
\hline Drip & 17.34 & 22.755 & 47.7 & 46.2 \\
\hline $\operatorname{LSD}_{0.05}$ & 0.76 & 0.80 & $\mathrm{~ns}^{*}$ & 1.5 \\
\hline \multicolumn{5}{|l|}{ Type of fertilizers } \\
\hline Humic acid & 17.46 & 21.725 & 49.3 & 47.00 \\
\hline Fulvic acid & 16.05 & 22.90 & 47.3 & 46.10 \\
\hline Soaked poultry glaucoma & 20.47 & 27.525 & 46.6 & 45.5 \\
\hline Soaked pigeons manure & 19.05 & 25.738 & 53.1 & 52.30 \\
\hline Soaked farmyard manure & 17.81 & 22.80 & 45.6 & 45.10 \\
\hline $\mathrm{LSD}_{0.05}$ & 1.05 & 1.57 & 2.3 & 2.6 \\
\hline \multicolumn{5}{|l|}{ Interactions between treatments } \\
\hline Sprinkler* Humic acid & & & 48 & 44 \\
\hline Sprinkler* Fulvic acid & & & 50 & 48 \\
\hline Sprinkler* Soaked poultry glaucoma & & & 47 & 48 \\
\hline Sprinkler* Soaked pigeons manure & & & 54 & 54 \\
\hline Sprinkler* Soaked farmyard manure & & & 47 & 46 \\
\hline Drip*Humic acid & & & 51 & 50 \\
\hline Drip*Fulvic acid & & & 44 & 44 \\
\hline Drip* Soaked poultry glaucoma & & & 47 & 43 \\
\hline Drip* Soaked pigeons manure & & & 52 & 51 \\
\hline Drip* Soaked farmyard manure & & & 44 & 44 \\
\hline $\mathrm{LSD}_{0.05}$ & ns & ns & 2.3 & 3.7 \\
\hline
\end{tabular}

*ns: non-significant

Effect of organic fertilizers on distribution of macronutrient concentrations in the studied soil

The effect of organic fertilizers on $\mathrm{K}$ distribution in soil are presented in Table (4) and 5 and Figure (1). The results showed that there was high accumulation of nitrogen, in the second layer $(15-30 \mathrm{~cm})$ in all organic treatments and irrigation systems, but concentration was higher in drip irrigation than that of the sprinkler irrigation. In general, adding soaked poultry glaucoma gave the high accumulation of nitrogen. So, peanut performance was better in terms of yield and quality when good cultivar sown under optimum nutrient management coupled with organic and inorganic nutrient management. This agree with the results of Veeramani and Subrahmaniyan, (2001).

Similarly, the effect of organic fertilizers on phosphorus concentrations are presented in Table 4 and 5 and figure (2). There was the result showed that high accumulation of phosphors, $\mathrm{P}$ in the first layer (0-15 $\mathrm{cm})$ are to $\mathrm{P}$ low movement that other nutrient. But, no difference between different organic fertilizers as well as irrigation system.

\section{Crop water productivity of peanut under two irrigation system}

Table 6 and (7) showed the effect of two modern irrigation systems on amounts of applied irrigation water in $\mathrm{cm}$, for peanut crop under sprinkler and drip systems and its crop water productivity expressed as $\mathrm{Kg}$ of peanut yield per cubic meter of water requirements. The total water requirements of peanut ranged from 655 to $730 \mathrm{~mm}$ throughout the growing season under sprinkler irrigation system and from 580 to $689 \mathrm{~mm}$ under drip irrigation system that mean drip irrigation save water by 12.9 and $6.9 \%$ than sprinkler system for two growing season, respectively. On the other hand the water productivity was high with sprinkler irrigation 
system than drip irrigation system in second growing season, it was 1.32 and $1.24 \mathrm{~kg}$ peanut $/ \mathrm{m}^{3}$ applied water for sprinkler and drip irrigation systems, respectively. These results agree with the results of Ahmed (1999), Elliott et.al (1988) and Kijne et. al. (2003).

Also, the effect of organic fertilizers on potassium concentrations in studied soil are presented on Table 4 and 5 and figure (3). The results showed that there was the high accumulation of potassium, $\mathrm{K}$ was high in the first layer $(0-15 \mathrm{~cm})$ like $\mathrm{P}$ differ from $\mathrm{N}$. Also, the high amount of potassium accumulation appear with adding soaked poultry glaucoma organic fertilizer.in two growing season and as well as irrigation system

Crop water productivity of peanut under two irrigation system

Table 4. The effect of organic fertilizers on concentrations of mineral Nitrogen, available phosphorus and exchangeable potassium on soil under irrigation systems season 2007

\begin{tabular}{|c|c|c|c|c|c|c|c|}
\hline \multirow[b]{2}{*}{$\begin{array}{l}\text { Organic } \\
\text { fertilizers }\end{array}$} & \multirow[b]{2}{*}{ Depth (cm) } & \multicolumn{3}{|c|}{ Sprinkler irrigation } & \multicolumn{3}{|c|}{ Drip irrigation } \\
\hline & & $\begin{array}{c}N \\
(\mu \mathrm{g} / \mathrm{g})\end{array}$ & $\begin{array}{c}P \\
(\mu g / g)\end{array}$ & $\begin{array}{c}K \\
(\mu g / g)\end{array}$ & $\begin{array}{c}\mathrm{N} \\
(\mu \mathrm{g} / \mathrm{g})\end{array}$ & $\begin{array}{c}P \\
(\mu \mathrm{g} / \mathrm{g})\end{array}$ & $\begin{array}{c}K \\
(\mu g / g)\end{array}$ \\
\hline \multirow{4}{*}{$\begin{array}{l}\text { Soaked } \\
\text { poultry } \\
\text { glaucoma }\end{array}$} & $0-15$ & 176.4 & 22.6 & 264.8 & 191.8 & 21.3 & 257.4 \\
\hline & $15-30$ & 228.5 & 16.2 & 190.0 & 240.1 & 19.5 & 188.9 \\
\hline & $30-45$ & 163.2 & 11.8 & 100.0 & 178.6 & 11.9 & 136.6 \\
\hline & $45-60$ & 101.2 & 8.5 & 88.7 & 113.2 & 7.6 & 107.4 \\
\hline \multicolumn{2}{|l|}{ average } & 167.3 & 14.8 & 160.8 & 180.9 & 15.1 & 172.6 \\
\hline \multirow{4}{*}{$\begin{array}{l}\text { Soaked } \\
\text { pigeons } \\
\text { manure }\end{array}$} & $0-15$ & 198.4 & 18.7 & 211.6 & 211.5 & 20.3 & 235.7 \\
\hline & $15-30$ & 230.5 & 15.3 & 192.1 & 265.4 & 15.6 & 191.4 \\
\hline & $30-45$ & 161.6 & 10.1 & 121.0 & 182.7 & 11.8 & 154.2 \\
\hline & $45-60$ & 119.6 & 6.2 & 107.5 & 127.9 & 7.7 & 124.0 \\
\hline \multicolumn{2}{|l|}{ average } & 177.5 & 12.6 & 158.5 & 196.8 & 13.9 & 176.3 \\
\hline \multirow{4}{*}{$\begin{array}{l}\text { Soaked } \\
\text { farmyard } \\
\text { manure }\end{array}$} & $0-15$ & 186.9 & 14.2 & 132.7 & 192.1 & 15.3 & 212.6 \\
\hline & $15-30$ & 182.1 & 12.7 & 112.4 & 230.5 & 14.4 & 108.3 \\
\hline & $30-45$ & 163.7 & 11.8 & 93.8 & 144.7 & 12.6 & 100.4 \\
\hline & $45-60$ & 106.8 & 7.9 & 80.5 & 122.0 & 8.1 & 85.7 \\
\hline \multirow[t]{2}{*}{ average } & & 159.9 & 11.7 & 104.9 & 172.3 & 12.6 & 126.7 \\
\hline & $0-15$ & 153.4 & 20.5 & 135.4 & 193.2 & 22.2 & 176.4 \\
\hline \multirow{3}{*}{ Fulvic acid } & $15-30$ & 193.2 & 15.4 & 146.8 & 200.3 & 17.2 & 166.0 \\
\hline & $30-45$ & 118.0 & 10.0 & 122.1 & 134.4 & 8.6 & 130.2 \\
\hline & $45-60$ & 98.8 & 6.7 & 86.7 & 117.0 & 7.3 & 88.6 \\
\hline \multirow[t]{2}{*}{ average } & & 140.9 & 13.2 & 122.7 & 161.2 & 13.8 & 140.3 \\
\hline & $0-15$ & 173.3 & 21.6 & 158.6 & 197.7 & 24.3 & 186.7 \\
\hline \multirow{3}{*}{ Humic acid } & $15-30$ & 200.2 & 17.5 & 148.2 & 203.5 & 16.2 & 223.4 \\
\hline & $30-45$ & 137.1 & 10.4 & 155.0 & 148.1 & 11.0 & 160.2 \\
\hline & $45-60$ & 100.2 & 6.2 & 96.2 & 118.0 & 7.0 & 75.1 \\
\hline average & & 152.7 & 13.9 & 139.5 & 166.8 & 14.6 & 161.4 \\
\hline
\end{tabular}

Table 6 and (7) showed the effect of two modern irrigation systems on amounts of applied irrigation water in $\mathrm{cm}$, for peanut crop under sprinkler and drip systems and its crop water productivity expressed as $\mathrm{Kg}$ of peanut yield per cubic meter of water requirements. The total water requirements of peanut ranged from 655 to $730 \mathrm{~mm}$ throughout the growing season under sprinkler irrigation system and from 580 to $689 \mathrm{~mm}$ under drip irrigation system that mean drip irrigation save water by 12.9 and $6.9 \%$ than sprinkler system for two growing season, respectively. On the other hand the water productivity was high with sprinkler irrigation system than drip irrigation system in second growing season, it was 1.32 and $1.24 \mathrm{~kg}$ peanut $/ \mathrm{m}^{3}$ applied water for sprinkler and drip irrigation systems, respectively. These results agree with the results of Ahmed (1999), Elliott et.al (1988) and Kijne et. al. (2003). 

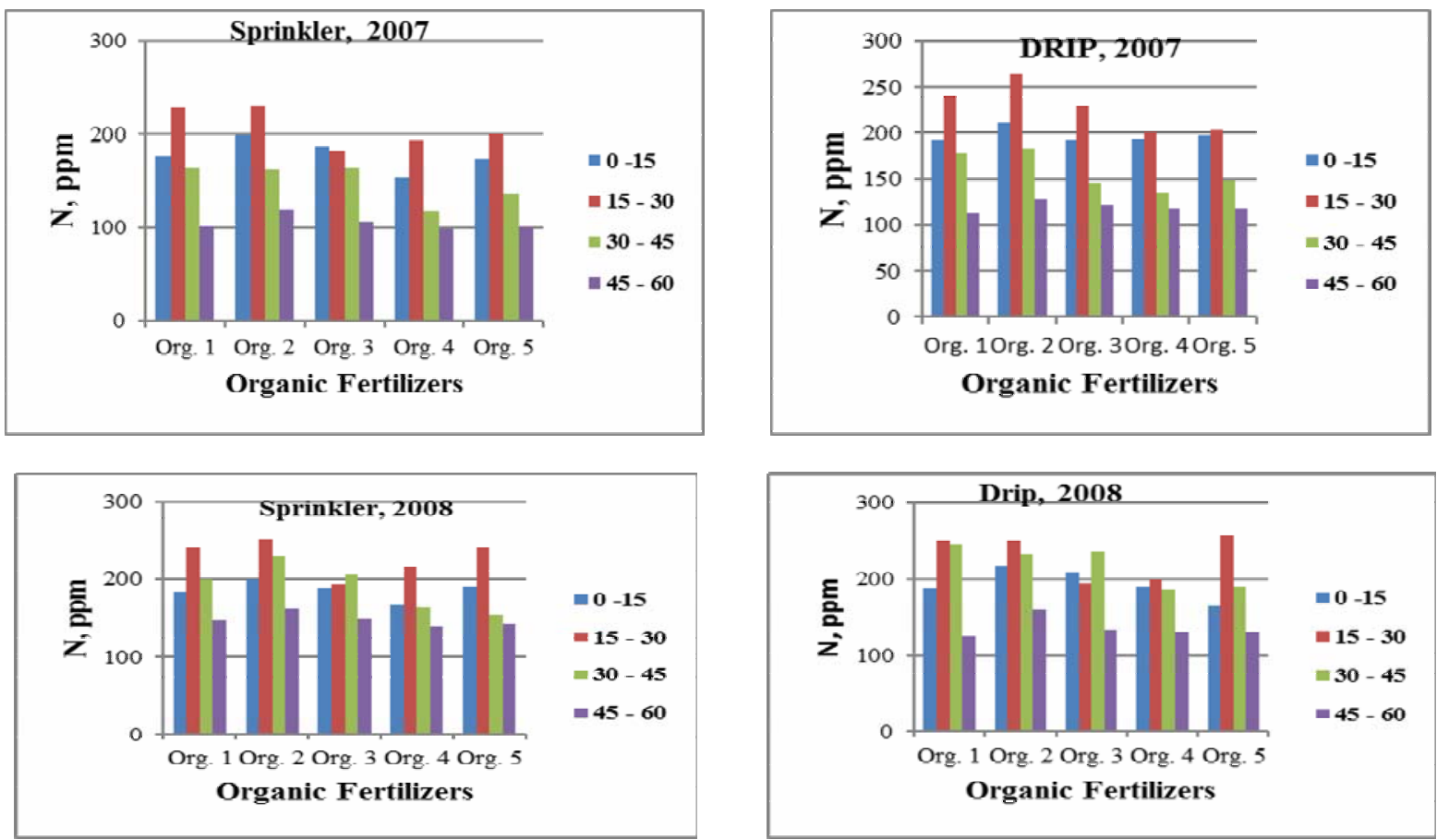

Org.1 = Soaked poultry glaucoma, Org.2 = Soaked pigeons manure, Org.3= Soaked farmyard manure, Org.4 = Fulvic acid, and Org.5 = Humic acid,

Fig .1.Effect of organic fertilizers on distribution of $\mathrm{N}$ in studied soil
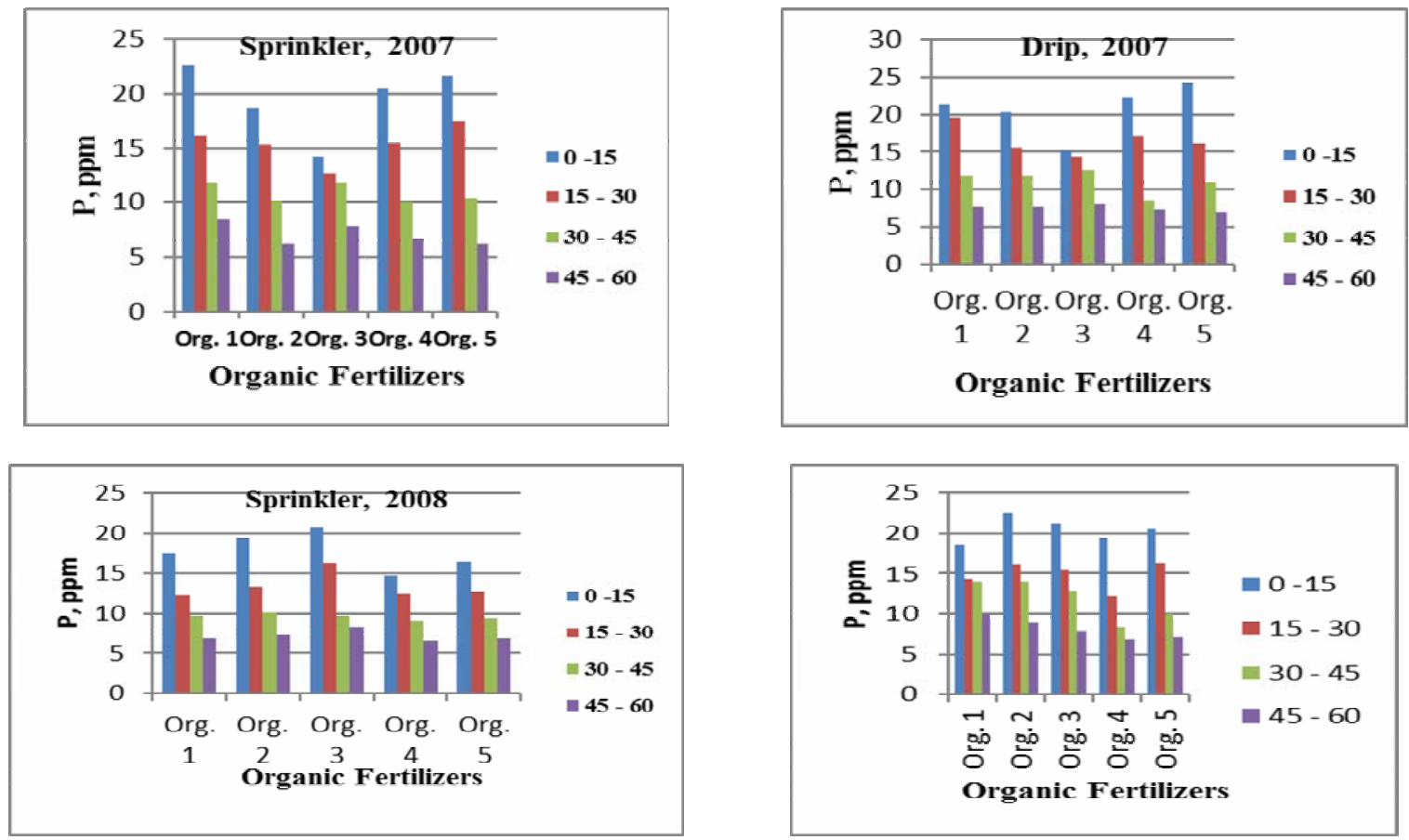

Org.1 = Soaked poultry glaucoma, Org.2= Soaked pigeons manure, Org.3= soaked farmyard manure, Org.4 = Fulvic acid, and Org.5 = Humic acid,

Fig .2. Effect of organic fertilizers on distribution of $P$ in studied soil 

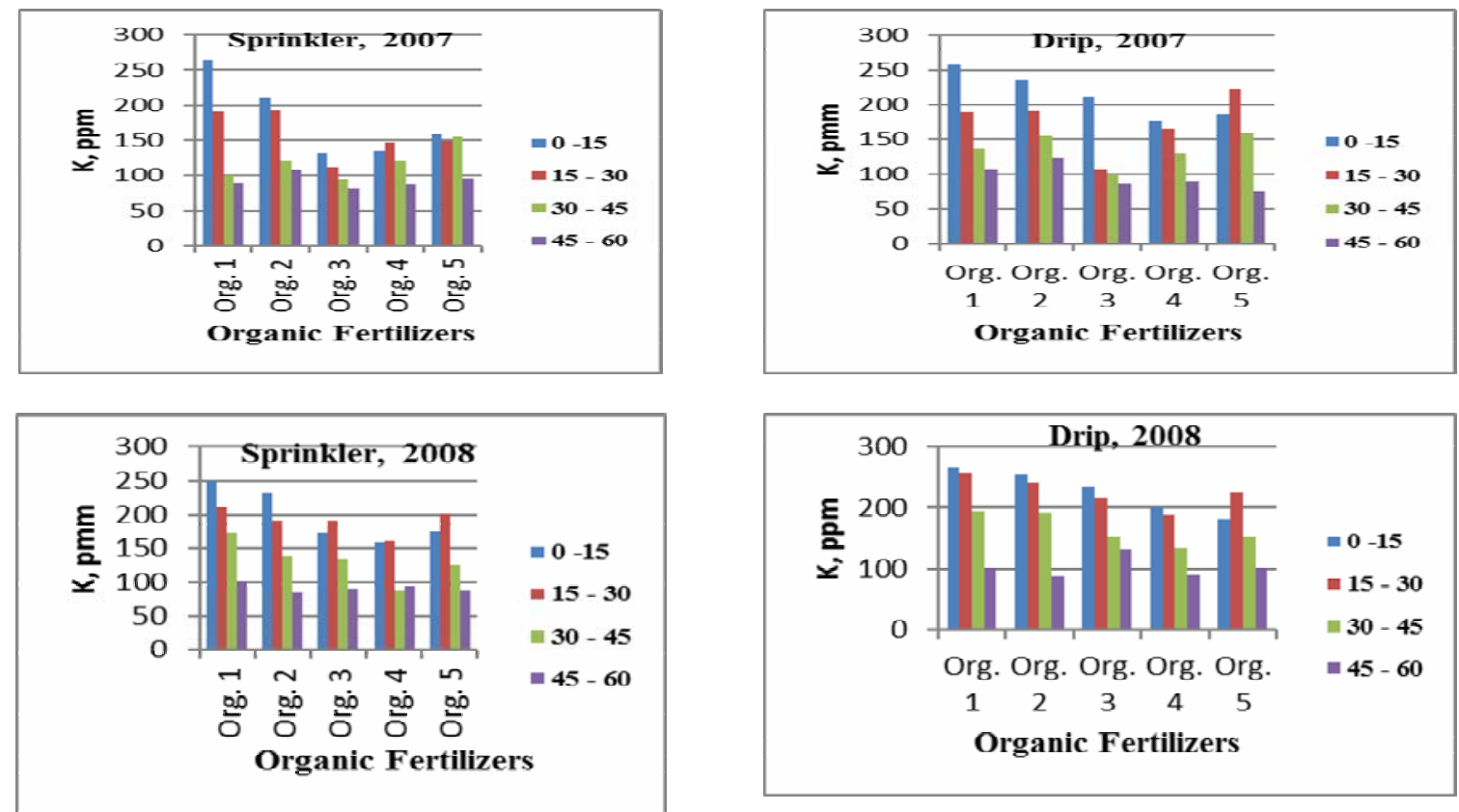

Org.1 = Soaked poultry glaucoma, Org.2= Soaked pigeons manure, Org.3= Soaked farmyard manure, Org.4 = Fulvic acid, and Org.5 = Humic acid,

Fig .3. Effect of organic fertilizers on distribution of $K$ in studied soil

Table 5. The effect of organic fertilizers on concentrations of mineral Nitrogen, available phosphorus and exchangeable potassium on soil under irrigation systems season 2008

\begin{tabular}{|c|c|c|c|c|c|c|c|}
\hline \multirow[b]{2}{*}{$\begin{array}{l}\text { Organic } \\
\text { fertilizers }\end{array}$} & \multirow[b]{2}{*}{$\begin{array}{c}\text { Depth } \\
\text { (cm) }\end{array}$} & \multicolumn{3}{|c|}{ Sprinkler irrigation } & \multicolumn{3}{|c|}{ Drip irrigation } \\
\hline & & $\begin{array}{c}N \\
(\mu \mathrm{g} / \mathrm{g})\end{array}$ & $\begin{array}{c}P \\
(\mu \mathrm{g} / \mathrm{g})\end{array}$ & $\begin{array}{c}\mathbf{K} \\
(\mu \mathrm{g} / \mathrm{g})\end{array}$ & $\begin{array}{c}\mathrm{N} \\
(\mu \mathrm{g} / \mathrm{g})\end{array}$ & $\begin{array}{c}P \\
(\mu \mathrm{g} / \mathrm{g})\end{array}$ & $\begin{array}{c}\mathrm{K} \\
(\mu \mathrm{g} / \mathrm{g})\end{array}$ \\
\hline \multirow{4}{*}{$\begin{array}{l}\text { Soaked } \\
\text { poultry } \\
\text { glaucoma }\end{array}$} & $0-15$ & 183.8 & 17.5 & 250.0 & 188.2 & 18.5 & 266.0 \\
\hline & $15-30$ & 241.6 & 12.3 & 210.8 & 250.6 & 14.3 & 257.3 \\
\hline & $30-45$ & 200.5 & 9.6 & 171.8 & 246.2 & 14.0 & 194.5 \\
\hline & $45-60$ & 147.2 & 6.8 & 100.4 & 125.4 & 10.0 & 100.5 \\
\hline average & & 193.3 & 11.5 & 183.2 & 202.6 & 14.2 & 204.5 \\
\hline \multirow{4}{*}{$\begin{array}{l}\text { Soaked } \\
\text { pigeons } \\
\text { manure }\end{array}$} & $0-15$ & 200.3 & 19.4 & 231.5 & 217.0 & 22.6 & 255.5 \\
\hline & $15-30$ & 252.3 & 13.3 & 190.7 & 251.0 & 16.2 & 242.4 \\
\hline & $30-45$ & 230.4 & 10.1 & 138.6 & 233.1 & 14.1 & 192.0 \\
\hline & $45-60$ & 162.0 & 7.2 & 84.5 & 160.6 & 8.9 & 87.9 \\
\hline average & & 211.2 & 12.5 & 161.3 & 215.4 & 15.45 & 194.5 \\
\hline \multirow{4}{*}{$\begin{array}{l}\text { Soaked } \\
\text { farmyard } \\
\text { manure }\end{array}$} & $0-15$ & 188.7 & 20.8 & 172.4 & 210.0 & 21.2 & 234.0 \\
\hline & $15-30$ & 193.2 & 16.3 & 190.2 & 195.4 & 15.5 & 216.3 \\
\hline & $30-45$ & 206.8 & 9.7 & 134.3 & 235.8 & 12.7 & 153.4 \\
\hline & $45-60$ & 149.4 & 8.3 & 90.5 & 133.6 & 7.9 & 130.0 \\
\hline \multirow[t]{2}{*}{ average } & & 184.5 & 13.8 & 146.8 & 193.7 & 14.3 & 183.4 \\
\hline & $0-15$ & 166.2 & 14.6 & 159.2 & 190.5 & 19.4 & 200.1 \\
\hline \multirow{3}{*}{ Fulavic acid } & $15-30$ & 215.8 & 12.4 & 160.1 & 200.0 & 12.2 & 188.2 \\
\hline & $30-45$ & 164.3 & 9.1 & 88.5 & 186.8 & 8.3 & 132.6 \\
\hline & $45-60$ & 140.1 & 6.6 & 93.4 & 130.5 & 6.8 & 90.5 \\
\hline \multirow[t]{2}{*}{ average } & & 171.6 & 10.7 & 125.3 & 177.1 & 11.7 & 152.8 \\
\hline & $0-15$ & 190.0 & 16.5 & 174.6 & 165.6 & 20.5 & 180.4 \\
\hline \multirow{3}{*}{ Humic acid } & $15-30$ & 241.2 & 12.7 & 200.3 & 256.4 & 16.3 & 225.5 \\
\hline & $30-45$ & 155.0 & 9.4 & 125.4 & 190.0 & 10.0 & 153.6 \\
\hline & $45-60$ & 142.5 & 6.8 & 87.6 & 130.0 & 7.1 & 100.8 \\
\hline average & & 182.2 & 11.35 & 147.0 & 185.5 & 13.5 & 165.1 \\
\hline
\end{tabular}


Table 6. Amounts of applied irrigation water in $\mathbf{m m}$, for peanut crop under sprinkler and drip irrigation systems, during 2007 and 2008 growing seasons

\begin{tabular}{llllcccc}
\hline \multirow{2}{*}{ Season } & Irrigation & \multicolumn{7}{c}{ Month } & \multirow{2}{*}{ total } \\
\cline { 2 - 7 } & system & May & June & July & August & September & \\
\hline \multirow{2}{*}{2007} & sprinkler & 55.0 & 168.0 & 194.0 & 181.0 & 57.0 & 655.0 \\
& drip & 41.0 & 142.0 & 185.0 & 163.0 & 49.0 & 580.0 \\
\multirow{2}{*}{2008} & sprinkler & 44.0 & 187.0 & 226.0 & 203.0 & 76.0 & 730.0 \\
& drip & 39.0 & 175.0 & 209.0 & 197.0 & 69.0 & 689.0 \\
\hline
\end{tabular}

Table 7. Water productivity of peanut yield

\begin{tabular}{|c|c|c|c|c|c|}
\hline \multirow{2}{*}{ Season } & \multirow{2}{*}{$\begin{array}{l}\text { Irrigation } \\
\text { system }\end{array}$} & \multicolumn{2}{|c|}{ Amounts of applied water } & \multirow{2}{*}{ yield $\mathrm{kg} / \mathrm{fed}$} & \multirow{2}{*}{$\begin{array}{l}\text { Water productivity } \mathrm{kg} \\
\text { peanut } / \mathrm{m}^{3} \text { applied water }\end{array}$} \\
\hline & & $\mathbf{m m}$ & $\mathrm{m}^{3} /$ fed & & \\
\hline \multirow{2}{*}{2007} & sprinkler & 655.0 & 2751.0 & 3000.42 & 1.09 \\
\hline & drip & 580.0 & 2436.0 & 2739.72 & 1.12 \\
\hline \multirow{2}{*}{2008} & sprinkler & 730.0 & 3066.0 & 4032.16 & 1.32 \\
\hline & drip & 689.0 & 2893.8 & 3595.29 & 1.24 \\
\hline
\end{tabular}

CONCLUSIONS

- The sprinkler irrigation system recorded significant increase peanut yield and oil percentage in comparison with drip irrigation system.

- The addition of soaked poultry glaucoma as organic fertilizer gave the highest yield of peanut, but the organic soaked pigeons manure resulted in high percentage of oil.

- The total water requirements of peanut ranged from 655 to $730 \mathrm{~mm}$ throughout the growing season under sprinkler irrigation system and from 580 to $689 \mathrm{~mm}$ under drip irrigation system.

- Water productivity of sprinkler irrigation system was higher than that of drip irrigation system in second growing season.

\section{ACKNOWLEDGEMENT}

We thank Dr. Mahmoud M. Attia (the head of project) for his critical and valuable suggestion during the preparation of experiment and writing the manuscript.

\section{REFERENCES}

Abdrabbo A. Abou Kheira, 2009. Macromanagement of deficit-irrigated peanut with sprinkler irrigation. Agricultural Water Management, 96: 1409-1420.

Ahmad, A. 1999. Yield response of groundnut grown under rainfed and irrigated conditions. In: Kirda, C., Moutonnet, P., Hera, C., Nielsen, D.R. (Eds.), Crop Yield Response to Deficit Irrigation. Kluwer Academic Publishers, Dordrecht, the Netherlands, pp. 128-135.

Attia, M. M.; A. Ramadan; and M. El- Moursy. 2008. Response of sweet potato to Mycorrihzae and irrigation in sandy treatments under drip irrigation in sandy soils. Alex. Sci. Exch. J. 29(4): 237-243.
Bandyopadhyay, P.K., Mallick, S. and S. K. Rana. 2005. Water balance and crop coefficients of summer-grown peanut (Arachis hypogaea L.) in a humid tropical region of India. Irrig. Sci. 23, 161-169.

Bilalis, D. A, A. Karkanisa, A. Efthimiadoua, A. Konstantasa, and V. Triantafyllidis. 2009. Effects of irrigation system and green manure on yield and nicotine content of Virginia (flue-cured) Organic tobacco (Nicotiana tabaccum), under Mediterranean conditions Industrial crops and products 29 (2009) 388-394.

Brown, I.R. 1999. Feeding nine billion.In .L.starke (ed) state of the world 1999. W.W. Norton and Co. New york $.230 \mathrm{pp}$.

Cetin, O., and L. Bilgel. 2002. Effects of different irrigation methods on shedding and yield of cotton. Agric. Water Manage. 54: 1-15.

Crescimanno G., A. De Santis, and G. Provenzano, 2007. Soil structure and bypass flow processes in a Vertisol under sprinkler and drip irrigation. Geoderma 138:110-118.

Doorenbos, J. and W.O.Pruitt. 1984. Crop water requirements Irrigation and Drainage paper no. 24. FAO, Rome Italy.

Elliott, R.L., Harp, S.L., Grosz, G.D., and M.A.Kizer. 1988. Crop coefficients for peanut evapotranspiration. Agric. Water Manage. 15: 155-164.

Fageria, N.K., V.C. Ballgar, and C.A. Johanes. 1997. Growth and Mineral Nutrient of Field Crop, second ed. Marcel Dekker. Inc., New York, USA, p. 494.

Faircloth, W.H., J.A. Ferrell, and C.L. Main. 2008. Weedcontrol systems for peanut grown as a feedstock. Weed Technol. 22: 584-590.

Hassan, F.U., A. Manaf, and M. Ejaz. 2005. Determinants of Oil and Fatty Acid Accumulation in Peanut Int. J. Agri. Biol. 7: 895-899.

Ismail, S.M. 2002. Design and Management of Field Irrigation System. (In Arabic), $1^{\text {st }}$ Ed Monsheat EL-Maaref . puplication. Alexandria. Egypt.

Israelsen, O.W. and V.E. Hansen. 1962. Irrigation principles and practices. $3^{\text {rd }}$ Edit. John wiley and Sons. Inc. New York. 
Jain, L.L., R.K. Panda, and C.P. Sharma. 1997. Water stress response function for groundnut (Arachis hypogaea L.). Agric. Water Manage. 32: 197-209.

Jensen, M.E. 1983. Design and operation of farm irrigation systems. Amer. Soc. Agric. Eng. Michigan, USA, P.827.

Karkanis, A., D. Bilalis, and A. Efthimiadou. 2007. Tobacco (Nicotiana tabaccum) infection by branched broomrape (Orobanche ramosa) as influenced by irrigation system and fertilization, under East Mediterranean conditions. J. Agron. 6: 397-402.

Kijne, J.W., R. Barker, and D. Molden. 2003. Improving water productivity in agriculture: editor's overview. In: Kijne, J.W., Barker, R.M.D. (eds.), Water productivity in agriculture: limits and opportunities for improvement. International Water Management Institute, Colombo, Sri Lanka, p. xi-xix.

Lin, XJ,B, F WangA, HS CaiA, RB LinA, CM HeA, QH LiA and Y LiA. 2010. Effects of different organic fertilizers on soil microbial biomass and peanut yield. 2010 19th World Congress of Soil Science, Soil Solutions for a Changing World 73: 1 - 6 August 2010, Brisbane, Australia. Published on DVD.

Lv WG, Q.W. Huang, and Q.R. Shen. 2005. The effect of organic fertilizer and organic-inorganic fertilizer application on soil enzymes activities during watermelon growing period. Journal of Nanjing Agricultural University 28: 67-71.

Plaut, Z., and M. Ben-Hur. 2005. Irrigation management of peanut with a moving sprinkler system: runoff, yield, and water use efficiency. Agron. J. 97: 1202-1209.
Ren ZG, Y.S. Chen, and F.Q. Tang. 1996. Effect of inorganic fertilizer combined with organic manure on themicroflora and enzyme activities in paddy soil. Plant Nutrition and Fertilizer Science 2: 279-283.

Sharmasarkar, F.C., S. Sharmasarkar, S.D. Miller, G.F. Vance, and R. Zhang. 2001. Assessment of drip and flood irrigation on water and fertilizer use efficiencies for sugarbeets. Agric. Water Manage. 46: 241-251.

Steel, R. G. and T.H. Torrie. 1960. Principal's procedures of statistics. Mc Grow Hill, NY. USA.

Suleiman, A., C.M... Soler, and G. Hoogenboom. 2007. Determination of the FAO-56 crop coefficients for peanut under deficit irrigation in a humid climate. In: The 2007 ASABE Annual International Meeting. Minneapolis, MN. Minneapolis Convention Center.

Sun RL, B.Q. Zhao, and LS. Zhu. 2003. Effects of long-term fertilization on soil enzyme activities and its role in adjusting-controlling soil fertility [J]. Plant Nutrition and Fertilizer Science 9: 406-410.

Veeramani, $P$ and K. Subrahmaniyan. 2001. Nutrient management for sustainable groundnut productivity in india - a review. International Journal of Engineering Science and Technology (IJEST) Vol. 3 No. 11: 81388153.

Vermeiren, L. and G.A. Jopling. 1984. Localized Irrigation. FAO. Irrigation and Drainage paper no. 36, Rome, Italy.

Zwart, S.J., and W.G.M. Bastiaanssen. 2004. Review of measured crop water productivity values for irrigated wheat, rice, cotton and maize. Agric. Water Manage 69: 115-133. 


\section{المالضص العري}

\section{الستجلبة محصط الفرل السوداني للأسمدة العضوبة تّه ظالمي الري بالشش والري بالتقيا.}

عبدالهادى خمليس عبدالحليم، لحمد عوض، محمد السيدمبسى

الدولجن أعلى النتاج من حبوب الفول السودالي حيث ك كـان rVV

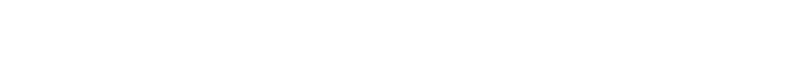

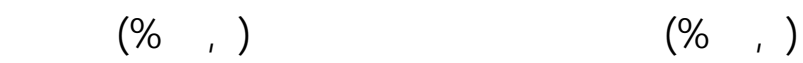

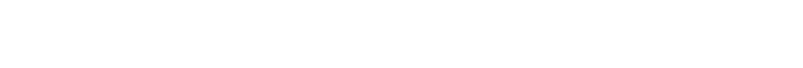

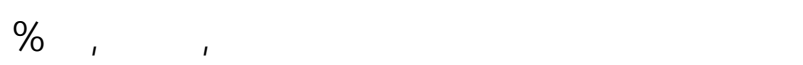
للموسمين على التوالي.

كلت الاحتيلجلت المائي ـة المثل مي لمح صصول الف ـول

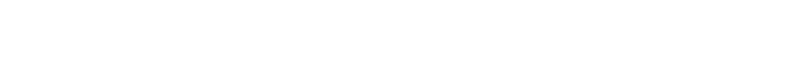

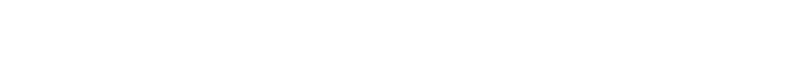

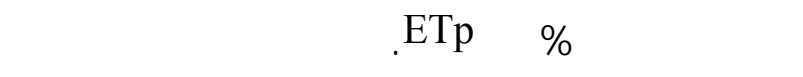

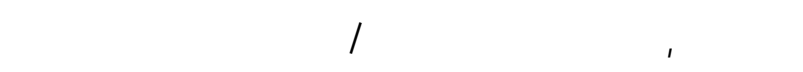
المضف وذك في الموسم الثاني.
لجريت تجربتين في مطقة الب ستان (النوباريـة) ف في

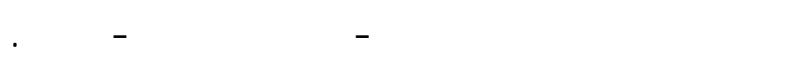
وكلتت الأهداف الرئيسية من هذه التجربة هو درلسة ت أثير الثنين من ظلم الري، (

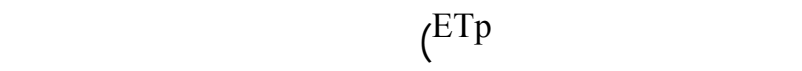

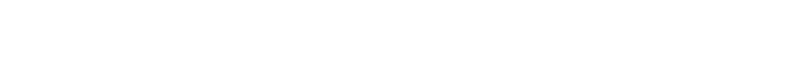

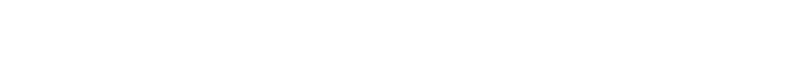
الماء. - الت وأوضهت النتائج أن هنك تأثير معنوي للفاء لـل بـ بن

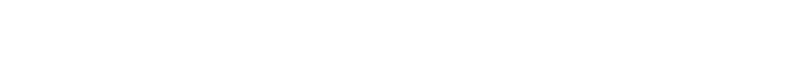

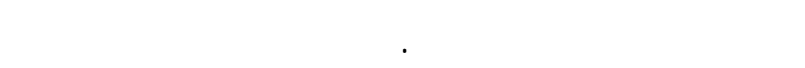

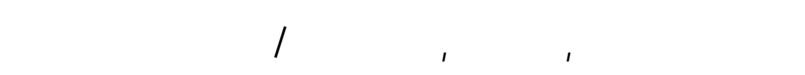

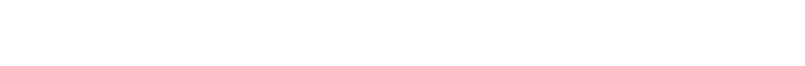

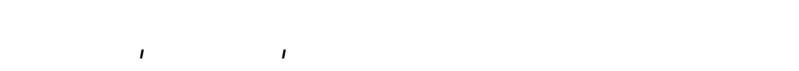

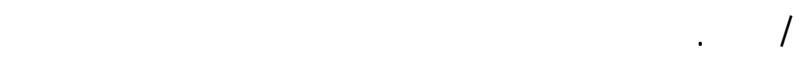

